Fashion Theory

The Journal of Dress, Body and Culture

\title{
Zurich, 1970. The Exhibition Balenciaga: Ein Meister der Haute Couture
}

\section{Gabriele Monti}

To cite this article: Gabriele Monti (2021): Zurich, 1970. The Exhibition Balenciaga: Ein Meister der Haute Couture, Fashion Theory, DOI: 10.1080/1362704X.2021.1905951

To link to this article: https://doi.org/10.1080/1362704X.2021.1905951

\section{曲 Published online: 16 Apr 2021.}

Submit your article to this journal ๘

Q View related articles $\longleftarrow$

View Crossmark data ¿ 
Gabriele Monti, Ph.D., is an Associate Professor at IUAV University of Venice, Italy. Among his research interests are theories of fashion design, fashion curating and visual culture, fashion and celebrity culture. He was associate curator of the exhibitions Diana Vreeland After Diana Vreeland (2012) and Bellissima: Italy and High Fashion 1945-1968 (2014-16). He published a book devoted to Italian fashion models, In posa. Modelle italiane dagli anni cinquanta a oggi (Marsilio, 2016). His last

\section{Abstract}

This article takes a new look at Balenciaga: Ein Meister der Haute Couture, the exhibition held at the Museum Bellerive in Zurich from May 31 to August 16, 1970. By exploring the materials preserved in the museum's archives (now at the Zurich University of the Arts), the study sets out to reconstruct this retrospective dedicated to Cristóbal Balenciaga and to consider its relevance to the museology of the Spanish creator. Examining these archival materials provides an extraordinary opportunity to reflect on the history of fashion exhibitions, on the genealogy of these three-dimensional artifacts and on the practice and discipline of fashion curating. How do we decide whom and what to 
project: the book and the exhibition Italiana. Italy Through the Lens of Fashion 1971-2001 (Milano, Palazzo Reale, February-May 2018 - Marsilio, 2018).

monti@iuav.it show? How do we construct a museum collection that represents fashion? To address these questions, this article analyzes not only the exhibition project, but also and above all the decision-making processes that preceded and shaped this exhibition in particular. Balenciaga: Ein Meister der Haute Couture was an exhibition produced in an institutional dimension which saw a close connection between the museum and the school of applied arts. At the root of this project lay the intentions of a school of fashion design: this allows us to think about the relationship between the design of fashion and the languages used in exhibitions of and for fashion.

KEYWORDS: Cristóbal Balenciaga, fashion curating, fashion exhibitions, fashion museology, Museum Bellerive

\section{Introduction}

The subject of this essay is the exhibition Balenciaga: Ein Meister der Haute Couture held at the Museum Bellerive in Zurich from May 31 to August 16, 1970. Curated by Erika Billeter, art historian and conservator of the museum from 1968 to 1975 , it provides an opportunity to reflect on the history of fashion exhibitions (almost from an archeological perspective), on the genealogy of these three-dimensional artifacts and on the practice and discipline of fashion curating. It is also a reflection on the history of fashion, seen as a discipline that defines itself in part on the basis of museum initiatives linked to the building of collections and the exhibition policies that are implemented. In fact, this exhibition is often cited in monographs and studies devoted to Cristóbal Balenciaga, but has never been described and analyzed in detail.

Exhibitions make a crucial contribution to constructing the history of fashion and to bringing the people who have shaped it into focus: they mold our cultural interpretation of the discipline of fashion. Balenciaga: Ein meister der haute couture was an exhibition produced in an institutional dimension, that of the museum bellerive (part of the kunstgewerbemuseum zürich, now called the museum of design, Zurich), which saw a close connection between the museum and the kunstgewerbeschule zürich, the school of applied arts where the course of fashion was taught. In other words, at the root of this project there were the intentions of a school of fashion design: this inevitably leads us to think about the relationship between the design of fashion and the languages used in exhibitions of and for fashion

We will see in fact that a gaze turned specifically on the design dimension of fashion suggests modes of display and three-dimensional narrations that do not necessarily coincide with choices that tend to move more in the direction of the exhibition of art (or of sculpture, as seems to have been favored by Billeter, who-it appears from the 
documents relating to the show- "took possession" of the project) or, of the exhibition that turns a fashion editorial's idea of the subject into spectacle (and here we come to suggestions that stem directly from Diana Vreeland's work at the Metropolitan Museum of Art in New York in the seventies and eighties). In this sense, as far as the choices of display are concerned, the exhibition in Zurich offered an implicit reflection on the relationship between fashion and art, sparking off a debate that has been going on in fashion studies since the outset, and which periodically flares up again. Not coincidentally, Valerie Steele (2012), director and chief curator of The Museum at the Fashion Institute of Technology (FIT), stresses in her contribution to the volume Fashion and Art (Geczy and Karaminas 2012), that the problematic nature of the relationship between art and fashion has been most clearly revealed with the entry of the latter into the museum and through the practice of exhibition. Significantly, Steele uses as a reference the viewpoint of Richard Martin-originally an art historian and critic who went on to become a fashion curator-who in his actions at The Museum at FIT and the Costume Institute of the Met between the 1980s and '90s, helped to formulate the terms of a debate and a wide-ranging exhibition activity in which the acts of curating and criticism were intertwined in a positive manner, contributing to the definition of the cultural status of fashion in its relationship with artistic and design disciplines. In an important essay that was devoted to Viktor \& Rolf, Martin (1999) wrote that in order to understand the work of the designer duo it was more useful to set aside the dichotomy between art and fashion and think in terms of contemporary visual culture, as a common framework within which to uncover the mechanisms that underpin the functioning of the two disciplines. And the curator and exhibition-maker Judith Clark has recently taken up this question again, through the project The Art of Fashion: Installing Allusions, helping to bring into focus an exhibition paradigm proper to fashion, in part and principally through an active comparison with artistic practices. ${ }^{1}$ Exploring the permanent collection of the Museum Boijmans Van Beuningen in Rotterdam and explicitly evoking Harald Szeemann's seminal exhibition A-Historische Klanken (A-Historical Sounds) staged there in 1988, Clark (2009) constructed an installation around five new projects commissioned from the same number of designers. In doing so, she suggested an idea of curating as a form of narrative that draws a parallel between the forms of art and the forms of fashion (the ones most closely connected with so-called Radical Fashion) through the concept of "allusion": a non-didactic way of approaching and suggesting things that recalls the common framework theorized by Martin and includes the role of visitors and their (unpredictable) questions with regard to an exhibition.

The exhibition in Zurich is positioned at the origin of this debate, precisely because it established a connection between exhibition practices proper to art and objects that pertain to the fashion system, while 
making clear the need for the latter to present itself as a disciplinary and cultural universe in its own right. In fact, it is not just the exhibition project that proves interesting, but also and above all the decision-making processes that preceded and shaped this exhibition in particular.

Through analysis of the documentation in the archives of the Zurich University of the Arts (letters, invoices, press review, images of the display), the article reconstructs, for the first time in detail, the process leading up to the exhibition, its mounting and successive stages, and places the experience in the context of the recent history of fashion exhibitions and the debate over fashion curating.

\section{The background of the exhibition}

The documentation relating to the exhibition is preserved in the archives of the Zurich University of the Arts. ${ }^{2}$ The Museum Bellerive, as was mentioned earlier, used to be part of the Museum für Gestaltung Zürich (Museum of Design, Zurich, at the time called the Kunstgewerbemuseum Zürich). This was connected in turn with Zurich University of the Arts (Zürcher Hochschule der Künste, ZHdK), with which the Kunstgewerbeschule Zürich, where the course of fashion was taught, was later merged. ${ }^{3}$ In 1968 the Museum of Design acquired the villa on Lake Zurich built in 1931 for the textile merchant Julius BlochSulzberger and moved part of its collection of applied arts there. The Museum Bellerive hosted temporary exhibitions and the collection of glass, ceramics and textiles until 2017, the year the museum closed; since 2018 the villa has housed the ZAZ (Zentrum Architektur Zürich). The museum's exhibition activities and collection were transferred in 2014 to the new campus of Zurich University of the Arts (ZHdK) at the Toni-Areal, the site of what used to be one of the biggest milk-processing companies in Europe.

The project of this retrospective was rooted in the desire to acquire a series of garments from the Balenciaga fashion house, following the news of its closure, made official in May 1968. It is possible to discern a not fully settled relationship between the school and the museum, i.e. between the needs of the teaching of fashion design and the modes of display required to present the products of that design in the best possible way.

A document drawn up in June 1970 by Verena Bischofberger, director at the time of the course of fashion design at the Kunstgewerbeschule Zürich, reconstructs the events that led up to the exhibition, introducing us to many of the people directly involved in the project. ${ }^{4}$ In the few reports published on this project, it is stated that the organizer of the exhibition was Gustav Zumsteg, friend of Balenciaga and owner of the Abraham textile company. Abraham supplied silk fabrics to the couturier (as well as to many other leading figures in Parisian couture). ${ }^{5}$ The involvement of Zumsteg was connected 
with the news of the fashion house's closure and Bischofberger's desire to acquire some of its models for the school for teaching purposes and the formation of what we could describe as the nucleus of a study collection. At her request, Mark Buchmann, president of the school from 1964 to 1973 and director of the museum, sent a letter to Zumsteg, asking him to support the school and the museum in the acquisition.

For the fashion school and the Museum Bellerive, Zumsteg represented a direct contact with Balenciaga. The fashion house had been closed down, but the couturier was still alive. On September 16, 1968, Bischofberger met Zumsteg, Balenciaga and Ramon Esparza, the couturier's right-hand man and the designer of the fashion house's hats, at the Grand Hotel Dolder in Zurich. The decision was made to organize a trip to Paris for Bischofberger so that she could select the models. It was not a donation, but a purchase at a reduced price (accompanied by some actual donations from the Maison Balenciaga and the Abraham firm): Zumsteg's engagement in the matter is evident, as discussions with Bischofberger continued in order to establish a price for the purchase of 10-15 pieces. Bischofberger was authorized to go to Paris, where at the end of November she made an initial selection of the pieces, in Zumsteg's presence. On February 6 and 7, 1969, Bischofberger was back in Paris to carry out a second selection of models. And then, on the occasion of a school trip to Paris in March 1969, she personally took some of the objects acquired back to Zurich. ${ }^{6}$

The direct involvement of the Abraham company makes us think about the role that the dimension of production can assume for cultural reflection-and not just from the perspective of the museum-on fashion. Gustav Zumsteg, a cultivated entrepreneur as well as patron and collector of art, was fundamental, right from the start in arranging the meeting with Balenciaga himself. Subsequently, in 1970, when it was evident that the exhibition project was growing more complex and therefore more costly, the Abraham firm made an exceptional contribution to the expenses of 5000 Swiss francs, along with a donation to the museum of fabrics produced for haute couture. Zumsteg was a fairly unusual case from an international perspective, and at the same time one that is very revealing of the cultural attitude that distinguished and pervaded the textile business in Switzerland, represented exceedingly well by Abraham (Swiss National Museum 2010).

These actions gradually came to be associated with the idea of holding an exhibition to celebrate the acquisition. The Museum Bellerive had opened on November 2, 1968: the Balenciaga project became a way of putting it to good use, and of marking the beginning of the constitution of a collection of clothes and objects linked to fashion. However, it is clear that in the early stages the interest in Balenciaga was connected chiefly with the school, because Bischofberger wanted the pieces for teaching purposes. In the aforementioned note dated June 10, 1970, she recalls that between September 1968 and November 1969 there were at 
least two occasions on which she tried to submit the Balenciaga acquisition to Erika Billeter, in order to stir her interest in a possible exhibition project. After these communications, director Buchmann informed Bischofberger that she was to plan the exhibition together with Billeter. At the beginning of February 1969, Cristóbal Balenciaga and Esparza visited the Museum Bellerive accompanied by Bischofberger, who remembers the couturier's enthusiasm for its spaces. ${ }^{7}$

Between the end of 1969 and the beginning of 1970 Bischofberger was progressively excluded from the project. ${ }^{8}$ No more information was provided on the actual cost of the exhibition, and it was only in April 1970 that it became clear to Bischofberger that it was going to cost much more than the original estimate, and that the whole of the ground floor would be placed at its disposal. ${ }^{9}$

So an interesting element emerges, that of a sort of handover between school and museum: in fact Bischofberger progressively disappears from the correspondence relating to the organization of the exhibition and Billeter assumes an increasingly central role in the project. ${ }^{10}$ This is an aspect that still helps us today to comprehend the cultural attitude that we have developed toward an exhibition on fashion, and the debate over the status of fashion at the time of its entry into the museum, viewed more as a form of art than as a discipline of design. We should not forget in fact that, at almost the same time, the end of 1969, Cecil Beaton wrote to the then director of the Victoria and Albert Museum in London, Sir John Pope-Hennessy, expressing his desire to put on an exhibition that would present the best of the women's fashion of the day. ${ }^{11}$

As for the choice to collect and display Balenciaga, in the case of Zurich it can be discerned from the correspondence between the various people involved in the project that the couturier and his work were recognized as playing a central role in the fashion system. The starting point was undoubtedly the idea of inserting him into the processes of teaching fashion design, even more than into the museum. The negotiations Bischofberger conducted with Balenciaga in Paris for the selection of models are particularly telling in this connection.

His creative ideas and the very high quality of his work have become points of reference that, unaffected by any fleeting tendency, will remain genuine works of art. [...] We have always wanted to possess some of his models, which could serve several purposes for us: they would be a stimulus and a benchmark of quality for our teaching activities and, at the same time, function as purely artistic productions and records of an era. (Letter from Bischofberger to Buchmann on November 27, 1968)

For these reasons Bischofberger asked for action to be taken with respect to the news of the closure of the atelier. In a way this already 
points to a tension between two different attitudes that is still pertinent to the cultural status of fashion today: on the one hand we have the dimension of the teaching of design; on the other, the problem of the entry of fashion into the museum, and its comparison with the so-called "fine arts." We will see that this tension also surfaced during the preparations: thus, the exhibition in Zurich seems to have taken on a "trailblazing" role, anticipating later experiences with shows devoted to fashion and the questions or doubts that these have raised.

\section{Mounting the exhibition}

After the opening of the exhibition, Bischofberger wrote a note, dated 10 June 1970, which confirms she had been excluded from its preparation. ${ }^{12}$

I saw, much to my regret, that the correlations have not been maintained; that, for example, a coat was not placed next to its "toile" (thus obliging the visitor who wishes to make a comparative analysis to walk through all the rooms several times) and that very many aesthetic and educational opportunitieswhich is what the objects on display and the aims of the Museum Bellerive were supposed to provide-have been wasted. Perhaps an expert ought to have been consulted. In spite of this amateurish arrangement, however, the result seems good, for the individual pieces are truly marvelous-but a great opportunity has been lost!

So, the initial idea of intertwining Billeter's point of view with Bischofberger's in the curation came to nothing, probably owing to the decision to place more emphasis on the exhibition as a spectacle rather than a learning experience. On June 11, 1970, Bischofberger also submitted a specific request to the school and museum, to access the materials not utilized for the exhibition-in particular the charts with fabric swatches relating to Balenciaga's collections-that could have turned out to be of great interest for the school. In her opinion, they would obviously have served to present a more nuanced picture of the couturier's creative milieu, in addition to emphasizing his relations with the Swiss textile industry and with Abraham and Zumsteg in particular.

Another person involved in mounting the exhibition was Gérard Miedinger, a graphic designer initially given the job of creating the poster for the exhibition. He was the brother of the better-known Max, celebrated for his design of the Helvetica typeface. ${ }^{13}$ Right from the start of my studies of fashion curating I was particularly struck by the beautiful cover of the small catalogue devoted to the retrospective of Balenciaga staged at the Costume Institute of the Metropolitan Museum of Art in New York that marked the beginning in 1973 of Diana 
Vreeland's stint as special consultant to the institution (Monti 2014). A careful examination of the catalogue and checklist of the exhibition in 1973 clearly reveals the relationship with an earlier event, the exhibition held at the Museum Bellerive in Zurich in 1970, whose poster has been preserved in the archives of the ZHdK: the cover of the 1973 catalogue is based on this poster (although its author is not named, as it is simply labeled as courtesy of the Museum Bellerive). The layout of the title is slightly different in the two versions, and the format of the catalogue "cuts off" the upper part of the poster, where the name of the Museum Bellerive headed information on the exhibition. ${ }^{14}$ The large " $\mathrm{B}$ " that dominates the composition and becomes the graphic structure of the image and the sophisticated color combination of blue and brown that utilizes the fields generated by the loops of the letter, have always conjured up for me-in a very immediate, almost automatic and certainly simplified manner-the idea of a decidedly "Swiss" style of graphics.

Miedinger's design for the poster was a sophisticated one, since it utilized a graphic style that was part of the fashion house's history (Figure 1). The B on which he worked and the word BALENCIAGA are composed in exactly the same upper-case typeface that was used for what today we would call the logo of the fashion house (Miller 2017, in particular chapter 3, "Commercial Culture").

The invoice made out by Miedinger's studio, dated June 30, 1970, indicates the elements and the actions that defined the exhibition project: Miedinger oversaw the design of the rooms where the exhibition was housed, the fitting of the clothes onto the mannequins, the preparation of the showcases and the display of the silk fabrics, and coordinated the work of finishing. The graphic designer was also involved in the selection of the photographs by Tom Kublin that punctuated the exhibition, especially with regard to the way the blow ups of the images relating to Balenciaga's creations were utilized (Figure 2). These held a dialogue with the garments on display and at the same time formed geometries that interacted with the architecture of the large hall on the ground floor of the Museum Bellerive, an architecture that was not originally designed for a museum but for the villa of a textile industrialist.

Thus, the large hall, with a view of the lake, was filled with a spectacularly choreographed staging of thirty stylized mannequins ordered from Schläppi, coated in aluminum and with no hair on their heads. Their style seemed to lose any reference to the female body and to turn into graphic signs, with exaggerated poses that emphasized the forms of the clothes in search of a decidedly theatrical effect (Figure 3). The illumination was boosted by spots that were trained like stage lights directly on the circular white daises on which the mannequins stood: in this way the clothes were "monumentalized" on raised pedestals. The circular shape of the daises held a dialogue with the arches that characterized the architecture of the room and the arrangement in horizontal lines of the smaller photos underscored the almost cinematic sequences 


\section{Figure 1}

Poster of the exhibition Balenciaga: Ein Meister der Haute Couture, Zurich, Museum Bellerive, May 31-August 16, 1970. Design Gérard Miedinger. Photo courtesy of the Museum für Gestaltung Zürich, Poster Collection, ZHdK.

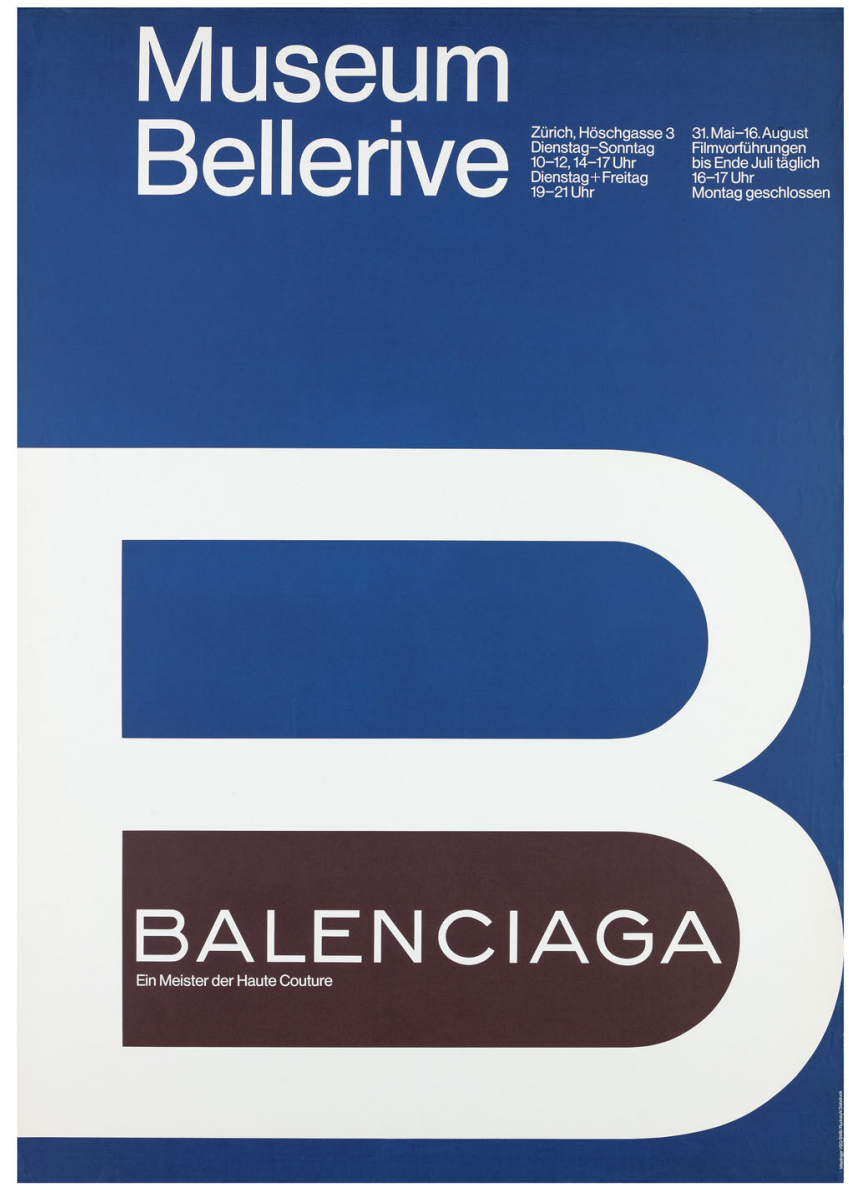

of garments (Figure 4). There were no glass cases to protect the clothing and visitors were able to move around the room, passing amongst the mannequins. Mirrors on the walls multiplied the space and ensured that the clothing was not viewed solely from the front.

A note sent by Billeter to the director Buchmann and dated March 26, 1970, is helpful in gaining a better understanding of how she handled the process of putting the exhibition together, as well as the changes that were made to the initial project in which the school of fashion had also been involved. We can infer from this correspondence that the project of staging an exhibition on Balenciaga had become relevant to an interpretation of the museum (of its mission), and of fashion in the museum. It is a curatorial vision that probably still resonates today in the circles (galleries, museums) that work on "exhibiting fashion," and that has to do with the quality of the objects produced by fashion in relation to their presence in a museum (whether in a 


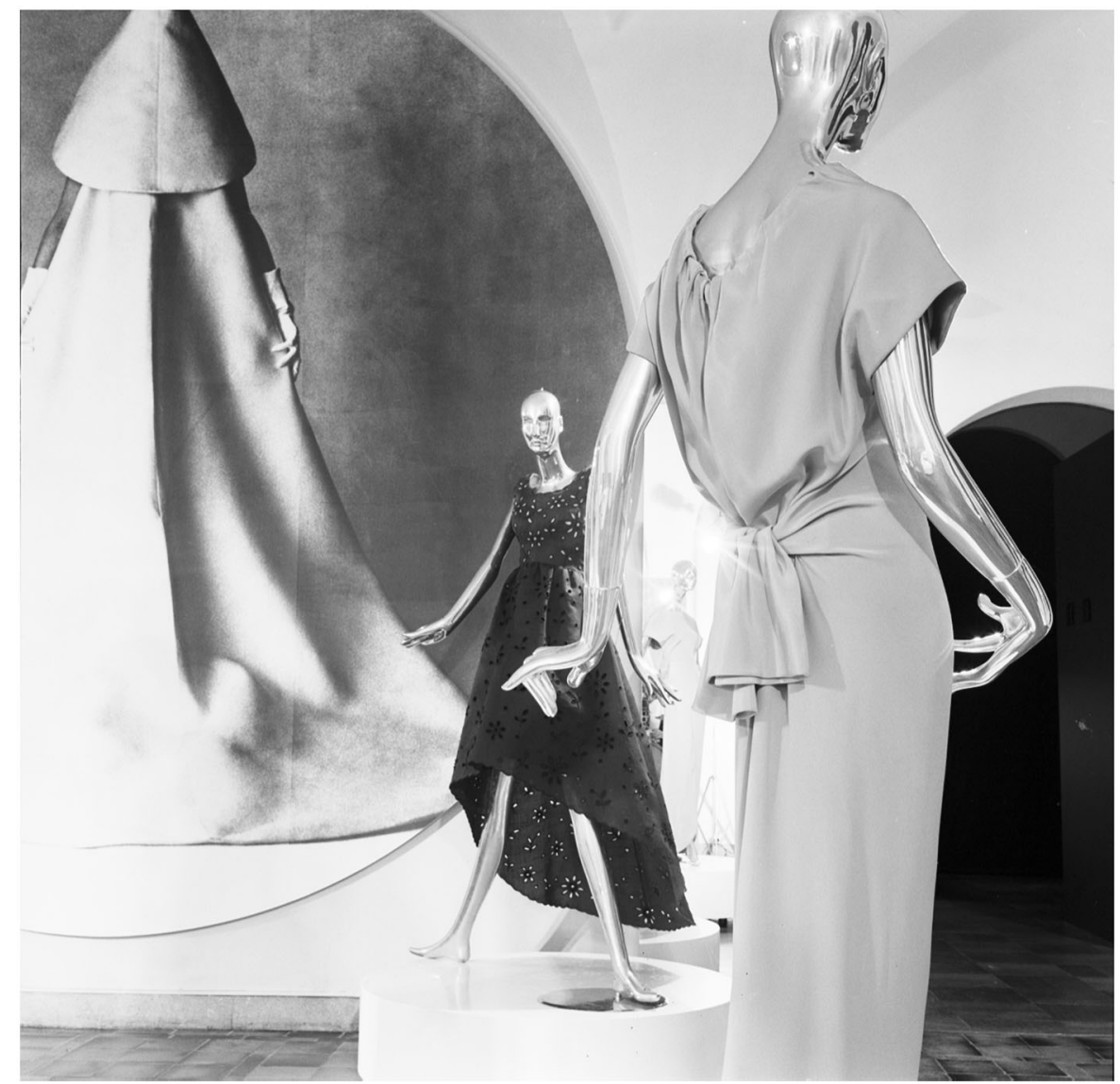

\section{Figure 2}

View of the exhibition Balenciaga: Ein Meister der Haute Couture, Zurich, Museum Bellerive, May 31-August 16, 1970. Photo courtesy of the Zurich University of the Arts / Archive.

temporary exhibition or the permanent collection). How to justify their presence in a museum? How to distance a display from the "shop window" effect? Billeter hints that the involvement of the graphic designer Gérard Miedinger was necessary in order to come up with a display capable of giving a special tone to the pieces exhibited, which were not new (they were not produced specifically for the exhibition) but at the same time could not be considered sufficiently "historical." Billeter stressed the difficulty of grasping and expressing this suspended time of fashion-close but not "now," and not far enough away to be viewed in a historical perspective-in her notes for the press briefing, a document for the presentation of the exhibition, which was being staged as part of the celebrations linked to Zurich's Juni-Festwochen (Zurich's June Festival Weeks).

His clothing resembles sculpture, constructed like a work of art [...]. In addition to the splendor of the dresses, the public will be 


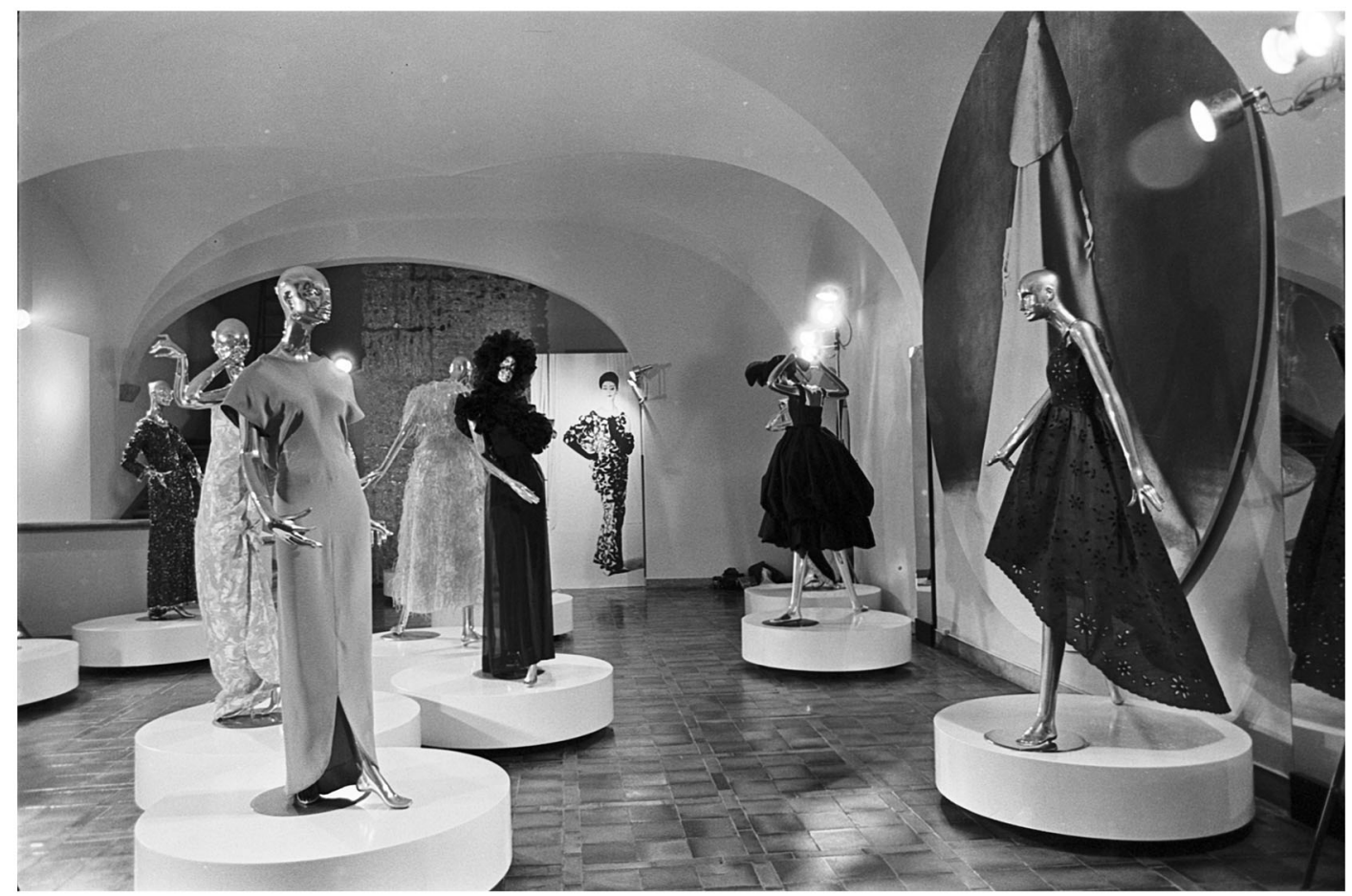

\section{Figure 3}

View of the exhibition Balenciaga: Ein Meister der Haute Couture, Zurich, Museum Bellerive, May 31-August 16, 1970. Photo courtesy of the Zurich University of the Arts / Archive.

able to discover something else: the cut of a garment is a work of architecture, which is structured according to the same laws and developed following the proportions of the body. (Notes for the press compiled by Billeter, 1970)

From these lines it is clear that, on the one hand, it was still necessary to "support" the decision to put the garments on display through a parallel with sculpture and the fine arts, and on the other, that the motivations for the exhibition had been reduced to the spectacular aspect of couture, enhanced through the uniqueness of the garment, the fact of its being "tailor-made" and the wealthy and highly sophisticated clientele. ${ }^{15}$ It is evident that the exhibition project took on a dimension that was intended to be celebratory and alluring for a public that would also include foreign tourists, given the insertion of the event into the framework of the Juni-Festwochen. This intention can also be deduced from the aforementioned letters that Billeter wrote to Buchmann between February and April of 1970: she explains that she has examined the models acquired for the museum collection under the supervision of Bischofberger and that "with such clothing, there is no way that we can 


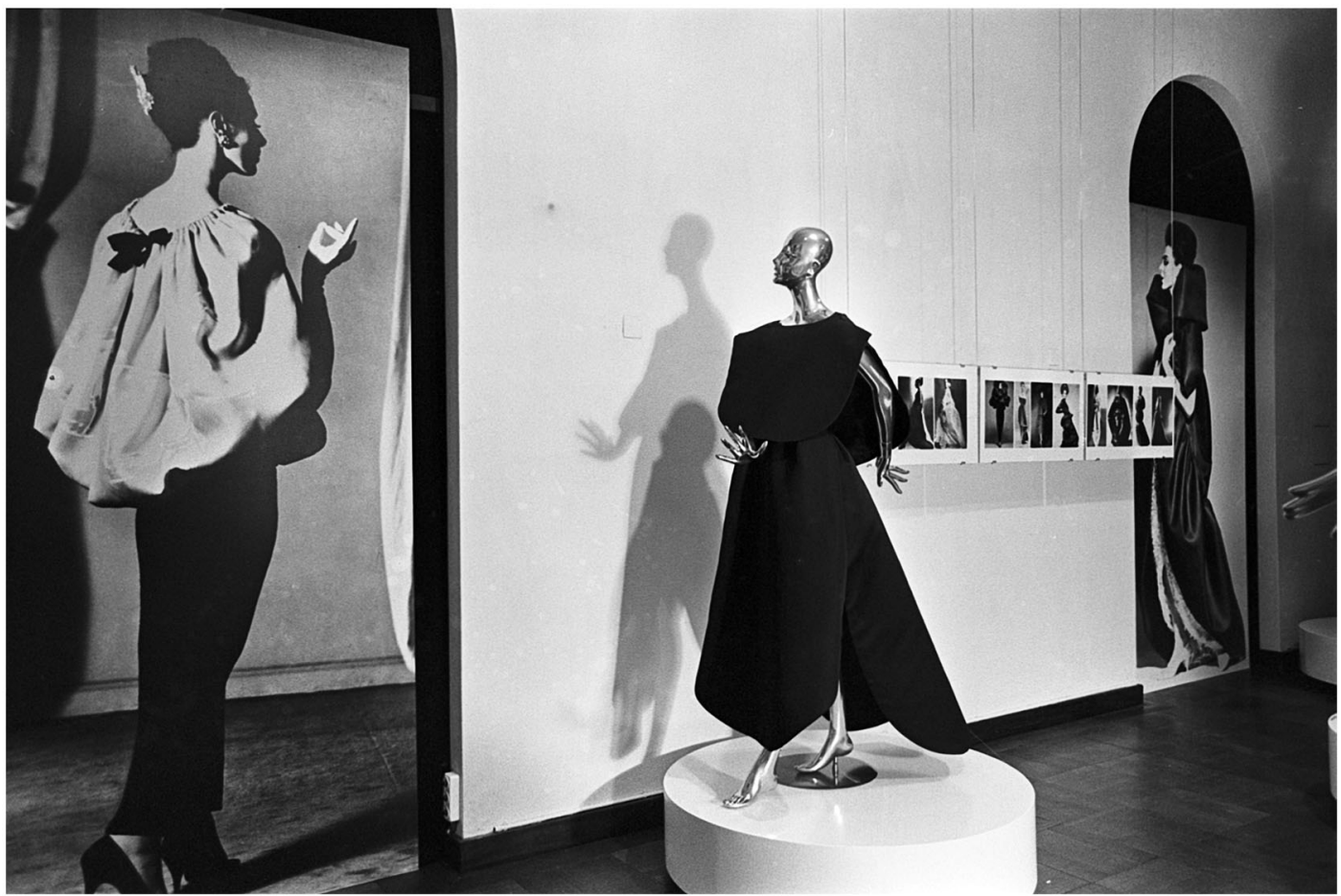

Figure 4

View of the exhibition Balenciaga: Ein Meister der Haute Couture, Zurich, Museum Bellerive, May 31-August 16, 1970. Photo courtesy of the Zurich University of the Arts / Archive.

organize an exhibition for the Juni-Festwochen, inasmuch as they do not illustrate Balenciaga's work in any way. It will be necessary, therefore, to borrow other models from private owners, something I am now trying to do."16 She goes on to say that special mannequins are needed, pointing out that the budget allocated is totally inadequate for an exhibition worthy of Balenciaga. And in April the situation changed: Billeter went to Paris to supplement the Bellerive's collection with the necessary loans. Balenciaga allowed her to look for the material needed in his archives. For the most part she chose evening and cocktail dresses to emphasize the theatricality and magnificence of haute couture. Through Hubert de Givenchy, Billeter also borrowed pieces belonging to the Countess Mona von Bismarck and Bunny Mellon. By displaying them, the exhibition would evoke Balenciaga's wealthy and socialite clients as well. So, in the end, most of the thirty mannequins in the exhibition wore evening dresses supplied directly by Cristóbal Balenciaga (along with hats and a few coats, including the one-seam coat) or by his wealthy clients. ${ }^{17}$ Two original Balenciaga models were lent by the Salon Tschannen, which sold Parisian couture in Zurich. In this way the collection of clothes for "teaching" was substantially supplemented and modified, and to some extent faded from sight in comparison with the 


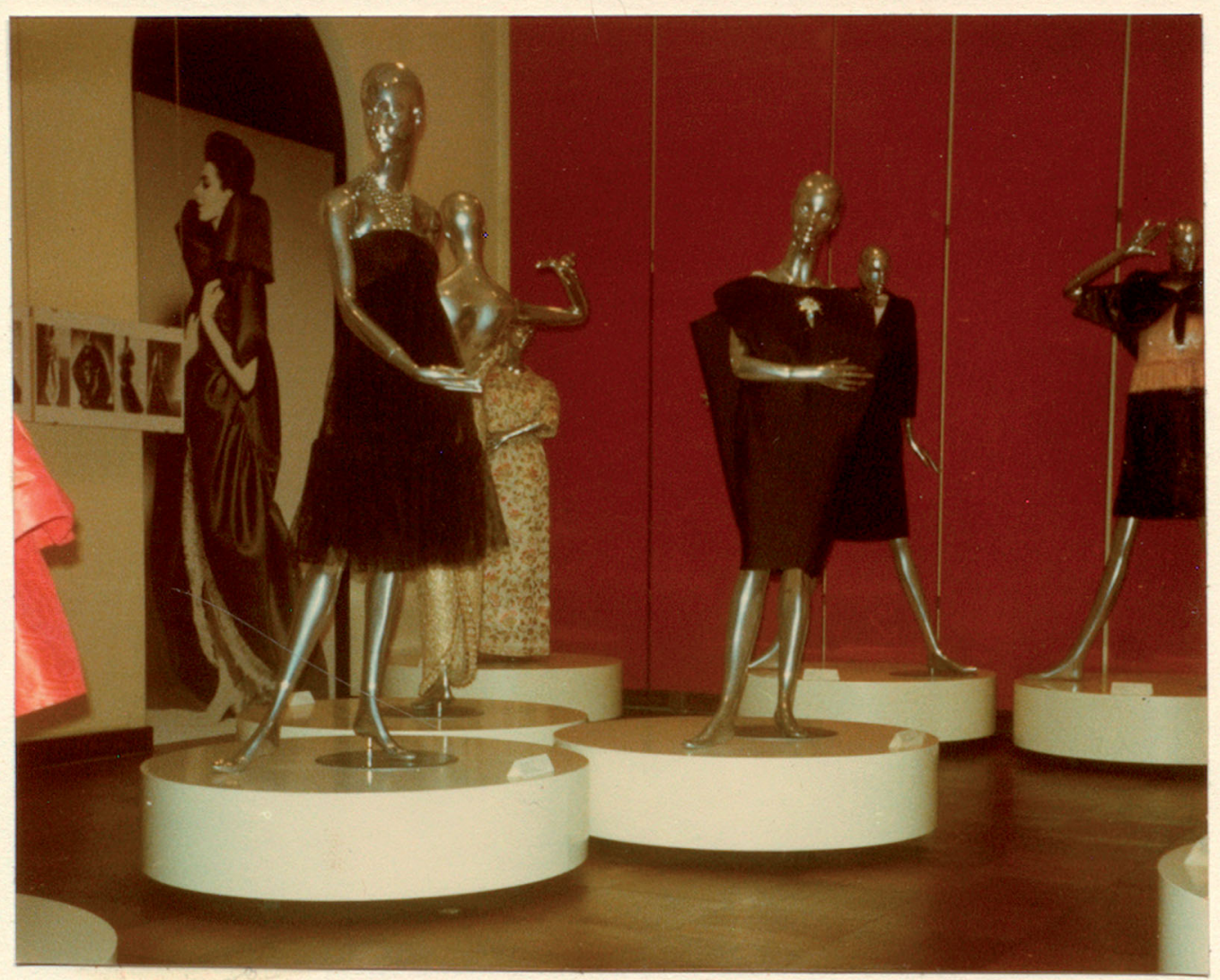

\section{Figure 5}

View of the exhibition Balenciaga: Ein Meister der Haute Couture (Zurich, Museum Bellerive, May 31-August 16, 1970) with Balenciaga's wide-winged cocktail dress of the fall/winter 1967 collection, in black Abraham gazar. Photo courtesy of the Zurich University of the Arts / Archive.

spectacular pieces chosen by Billeter (Figure 5). ${ }^{18}$ In the aforementioned note, quoted at the beginning of this paragraph, Bischofberger dwelled on the need to involve an "expert" in the exhibition, and hinted at a criticism of the role played by the conservator Billeter, who was acting without any specific technical expertise with regard to the objects she had to handle for this exhibition project.

The difficulty of defining the roles of the people involved in the exhibition arose with Miedinger, too. He was presented as an "organizer" and not as the designer of the exhibition, as he would have been credited today. In the press review his name was mentioned only once in an article and subsequently in a caption. It was a role not even remotely comparable with the one Billeter laid claim to for the exhibition.

As can be deduced from the press reviews in the archives, as well as from the items listed in Miedinger's invoice, the exhibition was not 
confined to the large central hall. It also occupied the smaller, adjoining rooms, in which showcases and fabrics were located. The hats along with the toile (muslin or fabric pattern) of the one-seam coat, were displayed here, but not the charts with fabric swatches even though they had been lent by Balenciaga, as Bischofberger did not fail to note with disappointment. Those materials suggested a dimension of fashion different from the spectacular and glittering one that is generally connected with couture. This unspectacular dimension is linked to the knowhow of fashion design and thus to its teaching. In Bischofberger's opinion, this technical perspective ought to be represented in an exhibition on Balenciaga, because he was unanimously considered as a master of the couture trade. Thus, a rift emerged between the curator-whose focus was on the imageries that shape fashion-and the conservator-who had a technical understanding of the pieces. The dispute seems to still be going on today, when we look at fashion's relationship with the museum (Marchetti 2016).

Billeter had an attitude that referred directly to the acts of storytelling that are interwoven in the staging of an exhibition. From her notes for the press, it seems clear that she considered it fundamental to set Balenciaga against the background of the timeline that connected the closure of his atelier in 1968, which had held almost unchallenged sway over fashion from the 1930s to the 1960s, to the changes in his clientele. Young women were no longer wearing couture, and not for economic reasons. These were the years of Swinging London, of the youthquake, of miniskirts, of the space age. They were also the years of youth rebellion against the status quo and of women's liberation.

There can be no doubt that the kind of acquisitions favored by Bischofberger made sense in the context of teaching and the specific processes of fashion design. The majority of the garments she preferred for the exhibition were for daytime wear, which were valuable as study material, although they were much less spectacular than the evening wear selected by Billeter. It should not be forgotten that the "famous" pattern of the one-seam coat (along with the actual coat) also appeared in this exhibition. The interest in this sort of material indicates an attention to the design processes and construction techniques of clothing that would be hard to disassociate from Bischofberger's concerns with regard to what should be put in the museum's collection, which was clearly for purposes of study.

The photographic documentation of the exhibition preserved in the archives (mainly in the form of negatives) focuses principally on the individual and particularly spectacular pieces displayed in the large hall on the ground floor. There is no trace of the fabrics, accessories and muslins presented in the other rooms. These images are intertwined with the descriptions to be found in the press review, made up of articles from both specialist magazines and newspapers. This documentation is fundamental to restoring three-dimensionality to the exhibition project 
and at the same time reflects in a very precise manner some of the questions that it tackled, although often leaving them without a clearcut answer.

The daily Luzerner Tagblatt of July 11, 1970 confirms the predominance of evening wear (cocktail dresses, evening dresses and outfits with long formal coats) and the lesser presence of daywear, although it did refer to an "interesting one-off piece," a checked woolen coat cut in a single piece and assembled with a single seam. This review, like many of the others, lingered on the "Spanish" theatricality of Balenciaga's fashion (trains, undulating flounces, copious drapery), sumptuously embroidered with applications of ribbons, feathers and sequins. It offered a very superficial view of Balenciaga's work, although it did pick up on a few elements that could have thrown light on the couturier's inventiveness and constructive flair.

In the issue of the illustrated magazine Die Woche published on June 10, 1970, appeared the article "Gestern Mode-heute Kunst" ("Yesterday Fashion. Today Art") by Gregor Henger, accompanied by a photographic reportage by Rob Gnant. The title is particularly interesting because it reflects to some extent the view of fashion in the museum and cultural prejudices about it, even though it was a museum devoted to design and the applied arts. This document from the archives is truly interesting because it presents a snapshot of the preparation of the exhibition, with a photograph of the curator Erika Billeter positioning Schläppi's stunning aluminum-coated mannequins before their dressing (Figure 6). Mannequins to which much attention was paid as they rendered the female body abstract and turned the garments into spectacular sculptures, overcoming the problem of them being seen as mere clothing. Highlighting the sculptural dimension of these objects appeared to make them works of art.

Vilma Hinn's article in the issue of the magazine Textil-Revue published on June 24, 1970, also has a particularly significant title, formulated as a question, one that grasps perfectly the problem at the center of the exhibition: "Balenciaga: Kunst oder Kunstgewerbe?" ("Balenciaga: Arts or Crafts?"). It is an age-old question, still relevant and certainly pertinent at that moment, of the cultural status of fashion in museums. Is it an art or an applied art? The structure of the article revolves around the question in the title. The journalist argues that although the hard and shiny stylized mannequins, with no wigs, are reminiscent of commercial displays, the presence of Balenciagas's pieces in the museum suggests they should be regarded as something that claims to be like painting, like sculpture, like art. She goes on to say that when looking at the fashion pieces displayed, one can no longer desire them. Since once they are posed on the mannequins they lose vitality and movement in their quest for artistic value.

The unresolved question of the cultural status of a fashion exhibition seems to find confirmation in the article that appeared in issue no. 3 in 


\section{Figure 6}

Erika Billeter positioning Schläppi's aluminum-coated manikins before their dressing. From the article "Gestern Mode - heute Kunst" (Yesterday Fashion - Today Art) published in Die Woche, June 10, 1970. Photo Rob Gnant. Press clipping courtesy of the Zurich University of the Arts / Archive.

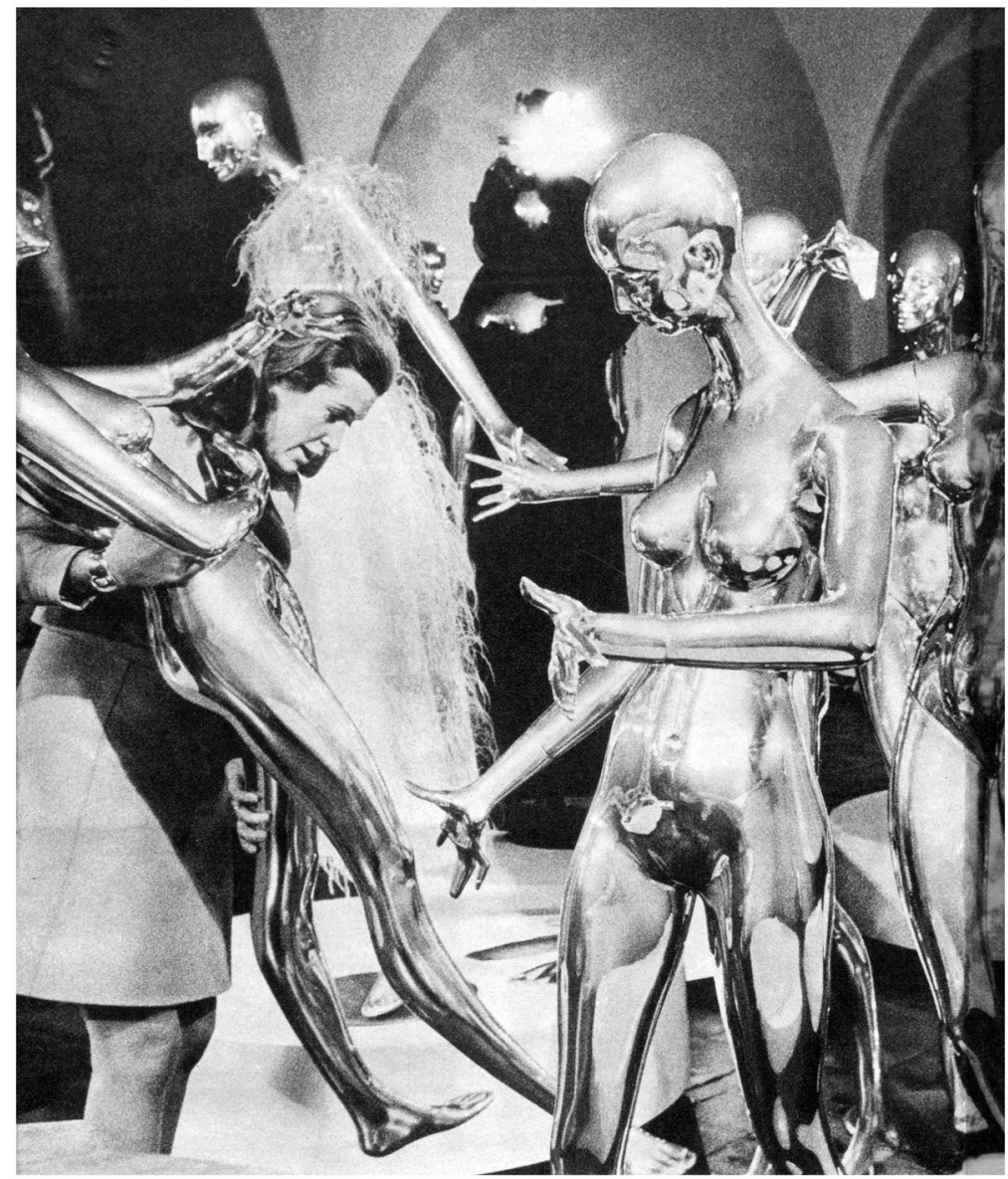

1970 of the magazine Textiles Suisses, house organ of the OSEC (Office Suisse d'Expansion Commerciale). ${ }^{19}$ The review quoted the long speech that Billeter gave at the opening of the exhibition in which the curator insisted on comparing Balenciaga's work to artistic creation, for it "showed that an excellent Haute Couturier works like a sculptor," producing "works of art to fit the body, in relation to the body, designed for the body" and following proportions proper to artistic practice, applying the golden rule: each of his creations is "more akin to a sculpture than to a foray into fashion." ${ }^{20}$ This is why, in Billeter's words, his place is in the museum.

It is not only because it can be considered one of the first exhibitions that a museum devoted entirely to a single designer (and moreover one who was still alive at the time, although no longer active), treated as an author worthy of making his entry into a museum as a "fine artist," that this exhibition proves to have been crucial. At the same time, it 
tackled directly one of the key questions related to the cultural status of fashion in the museum: should fashion be considered art or applied art?

It is undeniable that the display drew on elements from within the practice of fashion design as well as on an interpretation of fashion as a system that produces and feeds on images (and moving images) in order to communicate. ${ }^{21}$ The blow ups that frame the clothing in the architecture of the hall, the pictures that punctuate the sequences of garments, the films screened to convey the living dimension of the atelier were some of these images. The photographer Tom Kublin played a leading role in the image-making processes of Parisian couture. ${ }^{22}$ Kublin, of Hungarian origin (he was born in 1924), died prematurely in 1967, after opening a studio in Zurich in the fifties and then a branch in Paris. All the pictures in this exhibition were taken by Kublin, and the Studio Kublin provided the museum-which consequently purchased themwith copies of two films. ${ }^{23}$ The idea of using moving pictures for a fashion exhibition was undoubtedly an excellent one. At the same time, as we have seen from the reviews in the press, the visual materials and in particular the films were fundamental to sparking off some reflections that are still relevant today. ${ }^{24}$ In essence, this exhibition can be said to have been at the origin of a debate over the cultural paradigm with which we choose to view and interpret the discipline of fashion.

By its close the exhibition had received some 10,000 visitors.

\section{After Zurich}

The documentary films showing Balenciaga's collections from 1960 to 1968 and a unique film of Balenciaga in his workroom play an important educational role in the exhibition. The Metropolitan Museum is most grateful to Ramon Esparza and to the Musée Bellerive, Zurich, for making these films available. (The World of Balenciaga 1973, 77)

This acknowledgment was made at the end of the catalogue published on the occasion of the exhibition that ushered in the reign of Diana Vreeland at the Costume Institute of the Metropolitan Museum of Art in New York in 1973. It is important to note that in the archives in Zurich there are a number of folders devoted to the "stages" following the retrospective held at the Museum Bellerive, implicitly suggesting a relationship between these exhibitions and the one in Zurich. These folders are related to the exhibition in San Sebastián in 1972, the one in New York in 1973 and the one in Madrid in 1974: at first sight the show in Zurich seems to have become a sort of traveling exhibition, but that is not exactly the case. The only exhibition that can be considered to all intents and purposes a kind of successive stage to the one in Zurich was the one held in San Sebastián in August 1972. The documents that emerge from the files in the archives are very interesting, as 
they allow us to reflect on Billeter's awareness of what was at stake and on the viewpoint that the museum in Zurich had developed with respect to fashion.

What is certain is that the Museum Bellerive lent the Met one muslin pattern of Balenciaga's one-seam coat and a copy of Tom Kublin's film Haute Couture. The exhibition organized at the Museum Bellerive was a starting point, but the work of preparation of the loans requested by the Metropolitan Museum in New York, as is evident from a rapid perusal of the checklist drawn up in 1973, entailed a thorough reconnaissance of international museums and private lenders. ${ }^{25}$ Instead, the Museum Bellerive relied on the models acquired by the school of fashion, and above all on the later loans made by Balenciaga thanks to the intermediation of Zumsteg and those of garments belonging to two celebrity clients obtained through the intercession of Hubert de Givenchy: essentially it was not an exhaustive retrospective that was being planned, but a celebratory anthological exhibition.

The first exchange between Vreeland and Billeter took place in a letter dated September 12, 1972, typewritten on the headed notepaper of the Hotel de Crillon in Place de la Concorde in Paris, where Vreeland used to stay during her visits to the city. The letter is worthy of note because it makes clear the interests of Vreeland, who presents herself as a consultant to the Metropolitan Museum of Art. She has heard the impressions of Hubert de Givenchy, who visited the exhibition in the summer of 1970, and what interests her-in order for the project of the Met to turn out to be a "very splendid and very important show on Cristóbal Balenciaga"-are "the more extraordinary details." She is interested in the pattern (to be presented alongside the one-seam coat), in Kublin's films (in black and white and in color), and in the photos. She says that she knows she is asking a great deal, but the exhibition is really important and that the details that Billeter and Zumsteg can suggest are fundamental. The use of multimedia and of elements that convey Balenciaga's approach to design seems central for Vreeland. These are the aspects that she considers of importance in turning her shows at the Metropolitan into events that will be alluring and catchy for the audience (Clark and Frisa 2012; Monti 2013). What Vreeland wants most are the copy of the film Haute Couture that the Bellerive acquired from the Studio Tom Kublin and the muslin pattern of the one-seam coat, not the contents of the 1970 exhibition as a whole. ${ }^{26}$ And as Richard Martin and Harold Koda have pointed out (1993, 14), Vreeland's approach to exhibitions cannot be dismissed simply as an operation of pure entertainment carried out with spectacular dresses. And if we go back to the notes made by Bischofberger referred to previously, we can see that in the end Diana Vreeland accompanied the coat with its muslin pattern at the Met, realizing what Billeter had not achieved in Zurich. Although the idea of the director of the Zurich fashion school seemed too "didactic," displaying the single seam coat 
alongside its pattern would have helped visitors to the Bellerive to grasp the structural qualities of the piece and Balenciaga's mastery as a designer. It was an attempt to imagine an expository language that would present fashion through an allusion to the processes of its design. However, the muslin pattern seems to have become a sort of battleground between the school and the museum of Zurich. From a letter Billeter wrote to Esparza on December 17, 1973, we learn that the school laid claim to the "toile," asserting that it was part of the first acquisition made from Balenciaga, while Billeter argued that it had become the property of the museum through Zumsteg's intermediation. In fact, Billeter didn't know where it was: she knew that the film belonging to the Museum Bellerive had been sent to Esparza (together with the ones he himself had supplied); at the same time, she was trying to find out whether the muslin had been sent directly to Madrid.

In fact, the show in New York was followed by the staging of the exhibition El Mundo de Balenciaga from February 20 to April 5, 1974, at the Palacio de Bellas Artes in Madrid. Vreeland and Esparza were listed among the consultants to the exhibition, although as Stella Blum made clear in a letter to Billeter on October 5, 1973, it was not going to be an exhibition by the Metropolitan Museum of Art, as it would be organized directly by the Spanish institutions that had, nevertheless, been among the sponsors of the one at the Met. ${ }^{27}$

Luis Sargatal, director of the Barcelona-based Productoras Nacionales de Fibras Artificiales y Sinteticas (a member of the Comité International de la Rayonne et des Fibers Synthétiques), had written to Billeter on August 31, 1973, informing her of the intention to organize an exhibition devoted to Balenciaga in Madrid. In the letter he asked her to take the pieces displayed at the MET directly from New York, without having to return them to Zurich first, and requested other items from the archives of the Museum Bellerive. Billeter agreed to the loan and to the direct transfer of the materials from the MET to Madrid, as well as to a visit by Sargatal and Esparza to select some pieces from the collection of the Museum Bellerive.

But it is the exhibition in San Sebastián in 1972 that turns out to be more interesting with respect to the Museum Bellerive, as it was in fact assembled from the same materials as those used in Zurich in 1970. The archives of the Museum Bellerive contain some correspondence between Billeter and José Sánchez Eceiza, director of the Salon de la Elegancia, a trade fair held annually in San Sebastián. ${ }^{28}$ This city in the Basque Country was an important tourist resort with historical ties to Balenciaga. ${ }^{29}$ The city hall wanted to organize an exhibition to commemorate the recently deceased couturier, on the occasion of the Salon, which would be held for the ninth time from August 12 to 31, 1972. Billeter, who had been informed of the project by Zumsteg, wrote promising the garments of the museum, the photos of the Studio Kublin and the two films on Balenciaga, indicating the private lenders and providing 
the contacts with Schläppi for the mannequins. Ramon Esparza was also one of the facilitators/intermediaries of this project.

The Salon wanted to stage the exhibition in one of the halls adjacent to those used by the fair and wanted clothes and photos. They also requested Billeter travel to San Sebastián to help mount the exhibition. She replied that she could not and suggested a local set designer. The communications between the curator of Zurich and the people in San Sebastián show that the exhibition of the Salon de la Elegancia was handled in an amateurish way: the organizers asked Billeter to go to San Sebastián in July 1970, when the exhibition was going to be held just a month later, and after the event a fair number of problems emerged, to the point where Billeter asked Esparza to help to solve them. A large number of the pieces had been returned to Zurich from San Sebastián in an unacceptable state. They had all been packed into a single crate and arrived to the museum crumpled, and in some cases damaged as a result of being squeezed into the packing case. In addition, on October 17, five evening dresses and a coat were missing. Esparza managed to recover some of them, and they were brought from Paris to Zurich by one of Zumsteg's assistants. In a letter dated December 11, 1972, Billeter, while pointing out that one garment was still missing, thanked Esparza for his donation of hats and a coat, which shows that he was trying to make up for the harm. The experience was a dramatic but not wholly unpredictable one. The Salon had attempted to organize an exhibition for the purpose of entertainment in the context of a trade fair and it was not acting with the backing of a serious institution concerned about the treatment of fashion and design as cultural artifacts. Billeter probably let herself get involved in the project because Zumsteg and Esparza were acting as go-betweens, and was confident that the pieces would be properly looked after.

\section{Conclusion}

The project in Zurich was a groundbreaking one in the field of fashion exhibitions, and represented an important moment as far as the entry of fashion museums was concerned. At the same time, it shows that the Museum Bellerive's project wavered between the realm of art and that of design, without finding a specific point of view from which to present, and preserve, couture and fashion. Billeter does not seem to have been able to get away from the comparison with the so-called fine arts and the necessity to make her exhibition look artistic in museum terms, despite recognizing the importance of complementing the clothes with other artifacts capable of broadening the critical and historical perspective on fashion. She seems to have lacked an awareness of the need to find a language that could bring out the intrinsic values of fashion. But as Bischofberger suggested in the aforementioned note dated June 10, 1970, the presence of an expert would have proved useful: someone 
with a technical grasp of fashion design, able to look at objects and understand them, without, however, forgetting the complex system that sustains fashion, understood as a discipline in which the requirements of invention and authority are intertwined with sartorial and industrial production, and other aspects such as marketing and advertising. ${ }^{30}$

The experience in Zurich underlines the significance that Cristóbal Balenciaga had and still has today for the cultures of fashion. The research carried out by the couturier and the results he attained have been fundamental to the conception and formulation of a theory of fashion design and at the same time lie at the origin of a debate over the relationship between art and fashion that has pervaded the fashion studies of the last thirty years. Significantly, the aforementioned essay by Valerie Steele (2012) begins precisely by reflecting on the hypothetical presence of one of Balenciaga's pieces in a museum, and on how this object, despite originally belonging to the system of fashion and not to that of art, can acquire the aura of a work of art and spark off a reflection on the work of creators like Balenciaga that is capable of emphasizing its formal and artistic qualities. The entry of fashion into museums and the related practices of display have undoubtedly "contributed to blurring the line between art and fashion," (Steele 2012, 13) and it is no coincidence that Steele makes reference to a number of experiences in the 1990s that represent a fundamental stage in the process of bringing the exhibition paradigm of fashion into focus-also and above all through an active comparison with art. The first Florence Biennale entitled Looking at Fashion, held from September 21, 1996, to January 12, 1997, drew attention to the practices that art and fashion have in common and made clear the capacity of fashion to take on the contemporary in a direct and uninhibited (superficial) way (Monti 2016). The experience at the Bellerive occupies an ideal position at the origin of this debate, as can clearly be inferred from the clash between Bischofberger and Billeter over the creation of the collection of clothes for teaching purposes and over the approach to the mode of display.

The rediscovery today of this exhibition staged in 1970 is also of importance with respect to studies on Balenciaga: we can add this event to the history of the exhibitions devoted to the couturier (Miller 2017, 10-14), because it stands at the beginning of a process of identification of modes of display that were subsequently to be proposed again. In addition, it helps to define the concept of the retrospective devoted to an individual designer, even if Billeter's intentions do not seem to show any awareness of other experiences of exhibitions dedicated to fashion. This is an aspect that indicates the need to carry out further investigation of the birth and evolution of the retrospective as a means for the definition of fashion and its protagonists and for the reconstruction of their history.

What is certain is that this exhibition devoted to Balenciaga plays a central role in the reflection on the disciplinary autonomy of fashion, 
which is expressed both in the search for a paradigm of exhibition capable of conveying its constituent elements and in the definition of the didactic requirements of a fashion school. In the already cited letter that Bischofberger wrote to Buchmann in November 1968 to justify her desire to acquire materials from the Maison Balenciaga, she stressed the structural and design qualities of the objects that could be obtained for the school (models, hats, shoes and muslins), but not coincidentally also brought in the voice of Cecil Beaton, whose central role in the entry of fashion into museums has already been pointed out. Bischofberger quotes from Beaton's book The Glass of Fashion in support of her project:

His black woollen costumes, ceremonial sheaths of Byzantine embroidery, and extravaganzas of jet should be enshrined side by side with the peasant clothes, the sacrificial vestments and ceremonial robes to be found in our national museums, for they form a part of contemporary history. (Beaton 1954, 264)

Cristóbal Balenciaga and his work are fundamental precisely because they occupy a position that lies right at the heart of a tension between fashion understood as a discipline of design and fashion that makes a direct comparison with the arts at the moment of its entry into museums. A tension that still contributes to defining the cultural status of fashion today.

\section{Notes}

1. An important reference is the project that Judith Clark carried out between 2018 and 2019 at the invitation of the Cristóbal Balenciaga Museoa in Getaria: "Judith Clark was invited to respond to the museum's new curatorial route through the galleries with a new installation. Creating references to recent exhibitions dedicated to Balenciaga's work, the exhibition becomes a repository for museology as well as dress history": https:// judithclarkcostume.com/exhibitions/cristobal-balenciaga-fashion-an d-heritage-conversations/. Accessed August 20, 2020. The discovery in the Zurich University of the Arts archives of the folding map made by Clark on the occasion of the project Cristóbal Balenciaga. Fashion and Heritage-Conversations is particularly significant. This folding map clearly explains the themes and iconographic references she utilized to construct these museological conversations. See: de Lorenzo (2020).

2. When not otherwise indicated, the letters and documents cited in this article are in the Zurich University of the Arts / Archive (ZHdK Archive). Many of the documents present in the archives are in German and have been translated into English for this essay. 
3. The School of Applied Arts connected with the Kunstgewerbemuseum would later become the University of Design and Art (Hochschule für Gestaltung und Kunst Zürich, HGKZ), before merging with the Zurich University of the Arts (Zürcher Hochschule der Künste, ZHdK).

4. Verena Bischofberger, Vorgeschichte der Austellung Cristóbal Balenciaga, June 10, 1970.

5. In general, looking at chronologies of events related to Balenciaga and his fashion house, when it comes to the date of the exhibition in Zurich, the first retrospective devoted to the work of the still living couturier, great importance is assigned to Gustav Zumsteg in the promotion and organization of the project. See: Balenciaga (2011); Miller (2017).

6. It should be noted that some important pieces requested by Bischofberger were not initially acquired owing to a reduction in the funds available, but Bischofberger was later to "find" them in the exhibition as loans.

7. Initially, during this visit, Billeter proposed putting the models on display in the spaces on the upper floor of the museum, perhaps not immediately realizing the project's potential.

8. Letters from Billeter to Buchmann, February 4, March 26 and April 9, 1970.

9. Around 45,000 Swiss francs instead of the 10,000 initially allocated. In today's money that would be around 190-200,000 euros.

10. Letters from Billeter to Buchmann, February 4, March 26 and April 9, 1970.

11. The exhibition Fashion: An Anthology by Cecil Beaton in 1971 that sprang from this desire is considered a crucial moment for the systematic entry of contemporary fashion into museums in London. See: Clark and de la Haye (2014).

12. The note was made at the same time as the summary of the events leading up to the exhibition, also drawn up by Bischofberger.

13. The Miedingers were from Zurich and, furthermore, they were both former students at the city's Kunstgewerbeschule.

14. "The World of" is in capital letters and obviously placed above the name BALENCIAGA, whereas "Ein Meister der Haute Couture" is in upper and lower case and located underneath.

15. In this sense, the subtitle of the exhibition is revealing, with Balenciaga described as a "master" of haute couture.

16. Letter from Billeter to Buchmann, February 4, 1970.

17. Letter from Billeter to Madame Renée Tamisier, director of the Maison Balenciaga, thanking her for the welcome she had received at the atelier in Paris and for the loans made to the exhibition, April 1, 1970. Billeter had written to Balenciaga on January 16, 1970, to ask for these additional loans. 
18. While the number of pieces acquired by Bischofberger and the characteristics of these objects certainly made it necessary to borrow further items, at the same time the vision of someone who could understand them in structural terms, and not just from an exclusively formal perspective, should not be disregarded. In the collection of the Museum of Design in Zurich there is an iconic piece of Balenciaga, the black wide-winged cocktail dress, model no. 128 of the fall/winter 1967 collection, with its unmistakable form of an inverted cone. Looking carefully at the list of the acquisitions overseen by Bischofberger in early 1969, it seems that this piece was part of the group. It is a highly representative garment because it is a structurally complex piece and yet apparently very simple, made of gazar, the extraordinary fabric invented by Zumsteg in collaboration with Balenciaga. But it was sold in very small numbers because it was difficult to wear. This dress was shown in 1970, demonstrating to us today that a garment which is interesting from an "educational" viewpoint can be utilized for an exhibition that (also, but not only) aspired to be spectacular. Not coincidentally, Hiro's famous 1967 photograph of Alberta Tiburzi wearing this dress was on the cover of Lesley Ellis Miller's book (2017; also, see pages 72-73).

19. “Haute Couture im Museum.” 1970. Textiles Suisses, no. 3, September 11.

20. "Architecte pour les plans, sculpteur pour la forme, peintre pour la couleur, musicien pour l'harmonie et philosophe pour la mesure" are the words that Billeter uses to describe Balenciaga in the aforementioned article, with regard to the qualities that a couturier ought to possess. In reality they are Balenciaga's words, used by Zumsteg in his portrait of the couturier that appeared in the March 1968 issue of Vogue Paris. Also see Miller (2017, 50). It has been interesting to find in the archives this typewritten text signed by Zumsteg, which Billeter seems have appropriated.

21. Hubert de Givenchy wrote to Billeter after visiting the exhibition and found it excellent in the way it had captured the atmospheres that define Balenciaga, complimenting her in particular on the choice of showing Tom Kublin's films. Letter from Givenchy to Billeter, June 9, 1970.

22. See the recent interview with Tom Kublin's daughter Maria (Pountney 2010).

23. The film Die Goldene Stüble (10 minutes) is on one of the collections of 1965; the film Haute Couture (18 minutes) presents the couture of Yves Saint Laurent and the hairstyling of Alexandre de Paris as well as Balenciaga's work. Even though the second film does not focus exclusively on Balenciaga, it is extremely valuable because it is the one that shows him at work. Billeter does not seem to have grasped its documentary value, since she suggested 
the possibility of acquiring it principally for the fashion course. However the Museum Bellerive acquired and showed both films.

24. Two films-also made by Kublin-that were added to the materials requested from the Studio Kublin came directly from the fashion house in Paris, each on three reels, relating to the collections of 1962 and 1966.

25. "The Clothes and the Lenders," in The World of Balenciaga (1973, 66-77).

26. The coat was sent directly to the Met by Ramon Esparza.

27. In this letter Blum underlines the fact that over 150,000 people visited the exhibition on Balenciaga.

28. See https://www.diariovasco.com/20070824/san-sebastian/inelegan cia-salon-elegancia-20070824.html. Accessed August 13, 2020.

29. Balenciaga was born in Getaria in 1895 , and he set up in San Sebastián his first fashion house in 1917, which remained opened until 1968. See: Arzalluz (2011), Miller (2017).

30. The recent exhibition Balenciaga: Shaping Fashion curated by Cassie Davies-Strodder (Victoria and Albert Museum, London, May 27, 2017-February 18, 2018) has tried to "stage" a collaboration between school and museum in a very interesting manner: the museum invited students of the MA Pattern and Garment Technology course at the London College of Fashion to analyze Balenciaga's construction processes. They traced patterns from the original garments that were then digitized and improved so that they could be used to make calico toiles, displayed in the exhibition alongside Balenciaga's pieces. A way of drawing attention to the couturier's extraordinary technical skill, as well as making visible the language of design proper to fashion. See https://www.vam.ac.uk/articles/learning-from-the-master. Accessed August 17, 2020.

\section{Acknowledgements}

The author would like to thank the Archive of the Zurich University of the Arts $(\mathrm{ZHdK})$, and particularly Julia Flieg for her warm welcome and generous assistance.

\section{Disclosure statement}

No potential conflict of interest was reported by the author(s).

\section{ORCID}

Gabriele Monti (D) http://orcid.org/0000-0002-0181-3674 


\section{References}

Arzalluz, Miren. 2011. Cristóbal Balenciaga: The Making of a Master (1895-1936). London: V\&A.

Balenciaga. 2011. Cristóbal Balenciaga Museoa. Getaria: Fundación Cristóbal Balenciaga Museoa-Nerea.

Beaton, Cecil. 1954. The Glass of Fashion. London: Weidenfeld and Nicolson.

Clark, Judith. 2009. "Installing Allusions." In The Art of Fashion: Installing Allusions, 13-19. Catalogue of the Exhibition at the Museum Boijmans Van Beuningen, Rotterdam, September 19, 2009-January 10, 2010. Rotterdam: Museum Boijmans Van Beuningen.

Clark, Judith, and Amy de la Haye, eds. 2014. Exhibiting Fashion: Before and after 1971, with Jeffrey Horsley. New Haven: Yale University Press.

Clark, Judith, and Maria Luisa Frisa, eds. 2012. Diana Vreeland after Diana Vreeland. Catalogue of the Exhibition at Palazzo Fortuny, Venice, March 10-June 26, 2012. Venice: Marsilio.

de Lorenzo, Victoria. 2020. "Cristóbal Balenciaga, Moda y Patrimonio-Conversaciones. An Exhibition by Judith Clark at the Cristóbal Balenciaga Museoa, Getaria (San Sebastian), March 24, 2018-January 24, 2019." Fashion Theory 24 (3): 419-434. doi:10. 1080/1362704X.2019.1611306.

Geczy, Adam, and Vicki Karaminas, eds. 2012. Fashion and Art. London: Berg.

Marchetti, Luca. 2016. "Fashion Curating: Idées, Enjeux et Pratiques." In La mode esposée: Penser la mode par l'exposition/Fashion Curating: Understanding Fashion through the Exhibition, edited by Luca Marchetti, 21-28. Geneva: Head.

Martin, Richard. 1999. "A Note: Art \& Fashion, Viktor \& Rolf." Fashion Theory 3 (1): 109-120. doi:10.2752/136270499779165662.

Martin, Richard, and Koda, Harold, eds. 1993. Diana Vreeland: Immoderate Style. Catalogue of the exhibition at the Metropolitan Museum of Art, New York, December 9, 1993-March 20, 1994. New York: The Metropolitan Museum of Art.

Miller, Lesley Ellis. 2017. Balenciaga: Shaping Fashion. London: V\&A.

Monti, Gabriele. 2013. "After Diana Vreeland: The Discipline of Fashion Curating as a Personal Grammar." Catwalk 2 (1): 63-90.

Monti, Gabriele. 2014. "Fashion and the Museum. The Exhibition 'Are Clothes Modern?' and the Costume Institute." AIS/Design. Storia $e$ Ricerche 3. http://www.aisdesign.org/aisd/en/moda-e-museo-la-mostraare-clothes-modern-e-il-costume-institute.

Monti, Gabriele. 2016. "Carnival." In Across Art and Fashion, edited by Stefania Ricci, 253-256. Catalogue of the exhibition at the Museo 
Salvatore Ferragamo, Florence, May 19, 2016-April 7, 2017. Florence: Mandragora.

Pountney, Alice. 2010. "Glass Talks to Maria Kublin about Her Father - The Highly Influential Fashion Photographer Tom Kublin.” Glass, April 10. https://www.theglassmagazine.com/interview-with-mariakublin-father-fashion-photographer-tom-kublin/.

Steele, Valerie. 2012. "Fashion." In Fashion and Art, edited by Adam Geczy and Vicki Karaminas, 13-27. London: Berg.

Swiss National Museum, ed. 2010. Soie Pirate: The History and Fabric Designs of Abraham Ltd. Catalogue of the Exhibition at the National Museum, Zurich, October 22, 2010-February 13, 2011. Zurich: Scheidegger \& Spiess.

The World of Balenciaga. 1973. Catalogue of the Exhibition at the Costume Institute, Metropolitan Museum of Art, New York, March 23-September 9, 1973. New York: Metropolitan Museum of Art. 